\title{
PENINGKATAN AKTIVITAS DAN HASIL BELAJAR SISWA SMP MELALUI MODEL PEMBELAJARAN KOOPERATIF TIPE STUDENT TEAMS ACHIEVEMENT DIVISION DENGAN METODE EKSPERIMEN
}

\author{
Muhammad Dian Hadi Kesuma \\ Program Magister Pendidikan Fisika, Universitas Negeri Medan \\ dianhk@rocketmail.com
}

\begin{abstract}
Abstrak. Penelitian ini bertujuan untuk (1) Mengetahui aktivitas siswa kelas VIII SMP 2 Labuan Deli dalam kegiatan belajar mengajar dengan menggunakan metode eksperimen inkuiri. (2) Menentukan peningkatan aktivitas kelas VIII SMP 2 Labuan Deli dalam memecahkan masalah fisika setelah diterapkan metode eksperimen. Penelitian ini adalah tindakan kelas. Subjek penelitiannya adalah siswa kelas VIII SMP 2 TP Labuan Deli Semester 2 T.P. 2012/2013 berjumlah 31 orang siswa yang terdiri dari 13 lakilaki dan 18 wanita. Objek penelitian ini adalah peruses pembelajaran dengan menerapkan model pembelajaran kooperatif tipe STAD melalui metode eksperimen. Hasilpenelitian menunjukkan (1) Ada peningkatan hasil belajar siswa kelas VIII SMP Negeri 2 Labuan Deli ditunjukkan dari: (a) hasil belajar siswa tes pada siklus I, yaitu: rata-rata $=58,92$ dengan persentase ketuntasan $=$ 19,36 \%; (b) tes hasil belajar siswa pada siklus II yaitu rata-rata $=58,92$ persentase ketuntasan $75,70 \%$. Persentase ketuntasan naik sebesar $61,24 \%$ dan indeks gain ternormalisasi 0,41 atau kriteria sedang. (2) Ada peningkatan aktivitas siswa kelas VIII SMP Negeri 2 Labuhan Deli ditunjukkan dari siklus pertama hanya rata-rata 65,60 dan pada siklus kedua 81,65 . Hasil penelitian ini dapat digunakan sebagai masukan bagi guru dalam upaya untuk meningkatkan aktivitas dan hasil belajar siswa dengan menerapkan metode eksperimental.
\end{abstract}

Kata kunci: aktivitas pembelajaran siswa, hasil belajar, pembelajaran kooperatif tipe $S T A D$, metode eksperimen

\section{IMPROVEMENT ACTIVITIES AND STUDENT LEARNING RESULT SMP STUDENTS THROUGH COOPERATIVE LEARNING MODEL TYPE DIVISION ACHIEVEMENT TEAMS STUDENTS WITH EXPERIMENTS METHODE}

\author{
Muhammad Dian Hadi Kesuma \\ Department of Physical Education-Graduate State University of Medan \\ dianhk@rocketmail.com
}

\begin{abstract}
The objectives in these studies are (1) determine the activity of the eighth grade students of SMP 2 Labuan Deli in learning activities using an experimental method of inquiry. (2) Determine the increased student's activity in class VIII of SMP Negeri 2 Labuan Deli in solving physics problems after applied the experimental method. This study is a classroom action research.
\end{abstract}


Research subject is class VIII SMP 2 Semester 2 Labuan Deli T.P 2012/2013 numbered 31 students consisting of 13 men and 18 women. Object of this research is to apply the learning peruses STAD cooperative learning model through experimental methods. This result show (1) There is an increase in student learning outcomes Junior High School eighth grade 2 Labuan Deli is shown from: (a) the results of tests of student learning in the first cycle, namely: mean $=58.92$ with the percentage of completeness $=19.36 \%$; (b) tests of student learning outcomes in the second cycle is the average 75.70, percentage of completeness $=58.92 \%$. Completeness percentage increased by $61.24 \%$ and 0.41 normalized gain index or criteria being. (2) There is an increase in the activity of the eighth grade students of SMP Negeri 2 Labuan Deli is shown from the first cycle only average 65.60 and 81.65 in the second cycle. The results of this study can be used as input for teachers in an effort to increase the activity and student learning outcomes by applying experimental methods.

\section{Keywords: student learning activities, learning outcomes, cooperative} learning, Experiment Method

\section{PENDAHULUAN}

Pembelajaran Ilmu Pengetahuan Alam (IPA) khususnya Fisika berhubungan dengan cara mencari tahu tentang alam secara sistematis, sehingga bukanlah hanya penugasan kumpulan pengalaman berupa fakta-fakta, konsep-konsep atau prinsip-prinsip saja tetapi juga merupakan proses penemuan. Proses pembelajaran ilmu pengetahuan dan teknologi yang diberikan kepada peserta didik SMP/MTs di maksudkan untuk memperoleh kompetensi lanjut ilmu pengetahuan dan teknologi serta membudayakan berpikir ilmiah secara kritis, kreatif dan mandiri (permendiknas no 22 tahun 2006).

Sebagai sebuah lembaga pendidikan, sekolah menengah pertama memiliki peran yang sangat besar terhadap kemajuan dan perkembangan bangsa saat ini, dan juga memiliki harapan dan tujuan yang sama. Terbukti dengan visi dari SMP Negeri 2 Labuhan Deli yaitu unggul dalam prestasi, terampil, berbudaya berdasarkan iman dan taqwa, serta menjadi yang terbaik. Namun kondisi yang terjadi tidak sesuai dengan tujuan dan harapan yang ada, ini dapat di buktikan dengan rendahnya hasil belajar Fisika pada 2 tahun terakhir, ini terlihat dari persentase nilai hasil belajar Fisika
Persentase siswa yang memperoleh hasil belajar 65 ke atas pada mata pelajaran Fisika tidak mencapai $80 \%$ seperti yang diharapkan. Hal ini juga dapat disebabkan metode yang digunakan yaitu metode pembelajaran konvensional.

Berdasarkan observasi awal yang dilakukan peneliti diketahui bahwa masih kurangnya aktivitas belajar siswa seperti mencatat penjelasan guru, mengajukan pertanyaan, dan mengerjakan tugas yang diberikan oleh guru. Ini dipengaruhi karena masih rendahnya minat belajar siswa terhadap Fisika di sebabkan oleh beberapa faktor, seperti keadaan ekonomi, pendidikan orang tua yang rata-rata hanya tamat sekolah dasar, berdasarkan hasil wawancara peneliti dengan para guru yang berdomisili disekitar sekolah, dan siswa bahwa sekolah hanya untuk mendapatkan ijazah. Setelah mereka tamat, bagi siswa laki-laki disuruh membantu orang tua keladang, atau mencari ikan di laut, dan bagi siswa yang perempuan di suruh membantu pekerjaan dirumah dan bahkan ada yang mengalami pernikahan pada usia dini.

Peneliti menggunakan metode eksperimen untuk meningkatkan aktivitas siswa dalam pembelajaran Fisika. Metode eksperimen ini adalah cara penyajian pembelajaran dimana 
siswa melakukan percobaan dengan mengalami dan membuktikan sendiri sesuatu yang dipelajari. Harus disadari oleh seorang guru bahwa pelaksanaan eksperimen memerlukan suatu persiapan yang matang, memerlukan jangka waktu yang lama, dan membutuhkan ketekunan dan kesabaran. Agar penyelenggaraan eksperimen tidak mengalami kegagalan atau hambatan hendaknya guru berlatih atau mencoba terlebih dahulu.

Melalui eksperimen, siswa terlibat langsung dalam proses. Kesempatan untuk melaksanakan langkah-langkah dalam cara berpikir ilmiah, yaitu mulai merangkai alat percobaan sesuai dengan proedur kerja, mengamati serta mengukur, kemudian hasil percobaan dianalisis dan dipertanggung jawabkan dalam bentuk laporan eksperimen. Tujuannya adalah membantu siswa mengembangkan disiplin dan mengembangkan keterampilan intelektual yang diperlukan untuk mengajukan pertanyaan dan menemukan jawabannya berdasarkan rasa ingin tahunya.

Melalui model pembelajaran ini siswa diharapkan aktif mengajukan pertanyaan mengapa sesuatu terjadi kemudian mencari dan mengumpulkan serta memproses data secara logis untuk selanjutnya mengembangkan strategi intelektual yang dapat digunakan untuk dapat menemukan jawaban atas pertanyaan tersebut.

Berdasarkan latar belakang masalah yang telah dikemukakan di atas, beberapa masalah diidentifikasi yaitu: Kurangnya aktivitas siswa sehingga siswa kesulitan dalam menyelesaikan permasalahan Fisika; Masalah yang berkaitan dengan lingkungan peserta didik, pada umumnya pendidikan orang tua yang rendah mengakibatkan kurang perhatian terhadap pendidikan anaknya; Orang tua lebih mengharapkan anaknya membantu mereka disawah dan mencari ikan, kebanyakan dari mereka adalah petani dan nelayan. Secara umum, inilah keadaan sosial masyarakat peserta didik di SMP Negeri 2 Labuhan Deli. Masih banyak permasalahan yang lain di alami peserta didik. Berdasarkan latar belakang masalah, identifi- kasi masalah dan batasan masalah yang telah dikemukakan di atas, maka dibuat rumusan masalah: Apakah penerapan metode eksperimen dapat meningkatkan aktivitas belajar siswa di SMP Negeri 2 Labuhan Deli kelas VIII?

Tujuan penelitian yang ingin dicapai dari penelitian ini adalah untuk mengetahui aktivitas belajar siswa kelas VIII SMPN 2 Labuhan Deli dalam kegiatan belajar mengajar dengan menggunakan metode eksperimen Mengetahui peningkatan hasil belajar siswa kelas VIII SMP Negeri 2 Labuhan Deli dalam menyelesaikan masalah Fisika setelah diterapkan metode eksperimen. Penelitian ini diharapkan dapat memberikan manfaat khususnya bagi para pengajar Fisika tentang meningkatkan kemampuan profesionalnya dalam kegiatan belajar mengajar dan metode eksperimen menjadi alternatif untuk meningkatkan pembelajaran Fisika, Memberikan kesadaran untuk memperbaiki dan meningkatkan kualitas pembelajaran yang disesuaikan dengan tujuan, materi, karakteristik siswa dan kondisi pembelajaran, Mempunyai kemampuan dalam merancang model pembelajaran dengan metode eksperimen. Model pembelajaran yang akan dipadukan dengan metode eksperimen Student Teams Achievement Division (STAD).

Student Teams Achievement Division (STAD) merupakan pendekatan cooperative learning yang paling sederhana dan paling mudah dipahami (Arends, 2008). Pembelajaran kooperatif tipe STAD ini merupakan salah satu tipe dari model pembelajaran kooperatif dengan menggunakan kelompok-kelompok kecil dengan jumlah anggota tiap kelompok 4-5 orang siswa secara heterogen. Siswa di kelas tertentu dibagi menjadi beberapa kelompok/tim belajar dengan wakil-wakil dari kedua gender, dari berbagai kelompok rasial atau etnis, dan dengan prestasi rendah, rata-rata, dan tinggi. Di dalamnya siswa diberi kesempatan untuk melakukan kolaborasi dan elaborasi dengan teman sebaya dalam bentuk diskusi kelompok untuk memecahkan suatu permasalahan (Asma, 2006). Jadi, model pembelajaran kooperatif tipe STAD adalah salah satu model pembelajaran yang berguna 
untuk menumbuhkan kemampuan kerjasama, kreatif, berpikir kritis dan ada kemampuan untuk membantu teman serta merupakan pembelajaran kooperatif yang sangat sederhana. Metode diskusi yang digunakan dalam pembelajaran kooperatif tipe STAD ini dengan ceramah, tanya jawab, diskusi, dan sebagainya, yang disesuaikan dengan kebutuhan dan kemampuan siswa. Di awali dengan penyampaian tujuan pembelajaran, penyampaian materi, kegiatan kelompok, kuis, dan penghargaan kelompok. Guru menyajikan pelajaran, dan kemudian siswa bekerja dalam tim mereka mematikan bahwa seluruh anggota tin telah menguasai pelajaran tersebut. Kemudian seluruh siswa diberikan tes tentang materi tersebut, pada saat tes ini mereka tidak diperbolehkan saling membantu. Aktivitas belajar merupakan segala kegiatan yang dilakukandalam proses interaksi guru dan siswa dalam rangka mencapai tujuan belajar. Aktivitas yang dimaksudkan disini penekanannya adalah pada siswa, sebab dengan adanya aktivitas siswa dalam proses pembelajaran terciptalah situasi belajar yang aktif. Indikator keaktifan siswa yang diutamakan adalah melakukan eksperimen, bertanya, menjawab pertanyaan dan kerja sama dalam kelompok. Eksperimen adalah percobaan untuk membuktikan suatu pertanyaan atau hipotesa tertentu. Eksperimen dapat di lakukan di laboratorium atau di luar laboratorium, pekerjaan eksperimen mengandung makna belajar untuk berbuat, karena itu di masukkan dalam metode pembelajaran. Metode eksperimen adalah penyajian bahan pelajaran di mana siswa melakukan percobaan dengan mengalami untuk membuktikan sendiri suatu pertanyaan atau hipotesis yang sedang dipelajari.

Hasil belajar adalah keadaan individu yang mampu menguasai hubungan antara berbagai informasi dengan yang telah diperolehnya mengenai proses belajar. Menurut Sudjana (2010) hasil belajar adalah kemampuan yang dimiliki siswa setelah menerima pengalaman belajar. Horward Kingsley membagi tiga macam hasil belajar, yakni (a) keterampilan dan kebiasaan, (b) pengetahuan dan pengertian, (c) sikap dan cita-cita. Sedangkan Gagne membagi lima kategori hasil belajar, yakni a) informasi verbal, b) Keterampilan intelektual, c) Strategi kognitif, d) Sikap dan e) Keterampilan motoris. Hasil penelitian ini memposisikan tujuan penelitian terhadap hasil penelitian Okta (2010), Kholifudin (2011), dan Elizar (2012). Pada penelitian Okta (2010) dalam penelitiannya dengan menerapkan metode eksperimen pada pembelajaran Fisika dapat meningkatkan aktivitas belajar siswa berdasarkan indikatorindikator keaktifan belajar siswa menunjukan perubahan dan peningkatan pada penguasan konsep siswa dan hasil belajar yang cukup signifikan pada setiap siklus. Sedangkan Kholifudin (2011) diperoleh terdapat pengaruh metode eksperimet dan demonstrasi terhadap prestasi belajar Fisika siswa dan tidak ada pengaruh gaya belajar terhadap prestasi belajar Fisika pada pembelajaran dengan materi fluida statis serta tidak terdapat interaksi antara metode belajar dan gaya belajar siswa terhadap prestasi belajar Fisika. Kemudian Elizar (2012) mampu meningkatkan hasil belajar siswa yang terbukti dengan peningkatan aktivitas belajar siswa. Jadi, model pembelajaran kooperatif tipe $S T A D$ adalah salah satu model pembelajaran yang berguna untuk menumbuhkan kemampuan kerjasama, kreatif, berpikir kritis dan ada kemampuan untuk membantu teman serta merupakan pembelajaran kooperatif yang sangat sederhana.

\section{METODE PENELITIAN}

Penelitian ini merupakan penelitian tindakan kelas yang dilakukan oleh peneliti yang sekaligus sebagai guru bidang studi Fisika pada SMPN 2 Labuhan Deli. Adapun tujuannya dalam meningkatkan hasil belajar pada model pembelajaran kooperatif Tipe STAD dengan metode eksperimen. Penelitian Tindakan Kelas (PTK) merupakan kegiatan pemecahan masalah yang dimulai dari a) perencanaan, b) pelaksanaan, c) mengumpulkan data (observasi), d) menganalisis data atau informasi untuk memusatkan sejauh mana kelebihan atau kelemahan tindakan tersebut (refleksi). Ciri dari PTK 
adalah adanya perbaikan terus menerus sehingga kepuasan peneliti sering menjadi tolak ukur berhasil atau tidaknya siklus tersebut. Kemudian muncul permasalahan setelah dilakukan refleksi yang mencakup analisis, sintesis dan penilaian terhadap hasil pengamatan serta hasil tindakan, sehingga pada gilirannya perlu diadakan perencanaan ulang. Penelitian ini adalah kegiatan untuk memberi makna, menerangkan dan menyimpulkan hasil tindakan yang telah dilakukan. Berdasarkan kesimpulan pada kegiatan refleksi, suatu perencanaan untuk siklus berikutnya dibuat atau tindakan penelitian dipandang cukup.

\section{HASIL PENELITIAN DAN PEMBAHASAN Deskripsi Awal}

Berdasarkan observasi awal yang dilakukan diketahui bahwa masih kurangnya aktivitas belajar siswa seperti mencatat penjelasan guru, mengajukan pertanyaan, dan mengerjakan tugas yang diberikan oleh guru, ini dapat di buktikan dengan rendahnya hasil belajar Fisika pada 2 tahun terakhir, ini terlihat dari persentase nilai hasil belajar Fisika Persentase siswa yang memperoleh hasil belajar 65 ke atas pada mata pelajaran Fisika tidak mencapai $80 \%$ seperti yang diharapkan.

Peneliti menggunakan metode eksperimen untuk meningkatkan aktivitas siswa dalam pembelajaran Fisika. Metode eksperimen ini adalah cara penyajian pembelajaran dimana siswa melakukan percobaan dengan mengalami dan membuktikan sendiri sesuatu yang dipelajari. Melalui eksperimen, siswa terlibat langsung dalam proses. Kesempatan untuk melaksanakan langkah-langkah dalam cara berpikir ilmiah, yaitu mulai merangkai alat percobaan sesuai dengan proedur kerja, mengamati serta mengukur, kemudian hasil percobaan dianalisis dan dipertanggung jawabkan dalam bentuk laporan eksperimen.

\section{Data Aktivitas Kelompok Siswa Dalam Proses Pembelajaran Siklus I}

Dalam aspek aktivitas siswa hasil observasi pada siklus pertama dengan perole- han rata-rata skor 92,36 pada skor ideal 5 . Sedangkan perolehan persentasi nilai rata-rata aspek aktivitas siswa adalah 59,76\%. Dalam hal ini aspek aktivitas siswa tergolong kurang, yang mana aspek aktivitas siswa dikatakan berhasil jika mencapai lebih dari atau sama dengan $65 \%$. Fokus pengamatan observer terhadap aktivitas siswa pada penelitian ini ada tujuh indikator yaitu: Visual, Oral, Listening, Writing, Motor, Mental, Emotional.

Aktivitas kelompok siswa dalam proses pembelajaran Siklus I diketahui: untuk indikator I diperoleh rata-rata skor 69,52 dan termasuk aktivitas tinggi, indikator II diperoleh rata-rata skor 58,09 dan termasuk aktivitas cukup, indikator III diperoleh rata-rata skor 60,00 dan termasuk aktivitas cukup, indikator IV diperoleh rata-rata skor 58,09 dan termasuk aktivitas cukup, indikator $\mathrm{V}$ diperoleh rata-rata skor 54,28 dan termasuk aktivitas cukup, indikator VI diperoleh rata-rata skor 61,90 dan termasuk aktivitas cukup, indikator VII diperoleh ratarata skor 56,19 dan termasuk aktivitas cukup.

Data aktivitas kelompok belajar siswa ini dapat dilihat pada Gambar 1. berikut.

\section{siklus I}

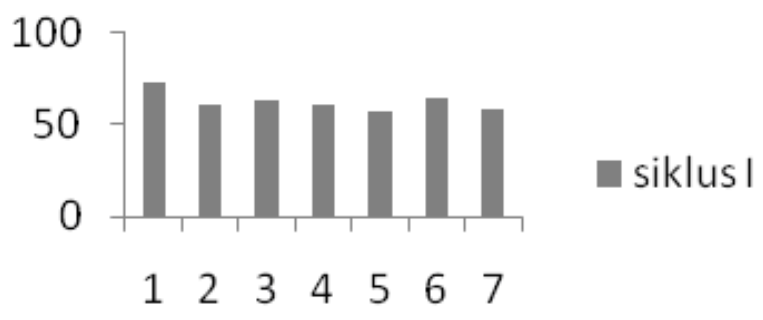

Gambar 1. Data aktivitas kelompok belajar siswa

Adapun hasil observasi terhadap aktivitas pembelajaran guru di kelas pada pertemuan pertama 65,60 , pada pertemuan kedua meningkat menjadi 76,00 dan pada pertemuan ketiga meningkat lagi menjadi 79,20. Meskipun nilai peningkatannya kecil, tetapi aktivitas pembelajaran yang dilakukan guru di kelas tetap mengalami peningkatan. 


\section{Data Siklus II}

\section{Data Aktivitas Kelompok Siswa Dalam Proses Pembelajaran Siklus II}

Dalam aspek aktivitas siswa hasil observasi pada siklus kedua dengan perolehan rata-rata skor 92,36 pada skor ideal 155. Sedangkan perolehan persentasi nilai rata-rata aspek aktivitas siswa adalah 59,76\%. Dalam hal ini aspek aktivitas siswa tergolong kurang, yang mana aspek aktivitas siswa dikatakan berhasil jika mencapai lebih dari atau sama dengan $65 \%$. Fokus pengamatan observer terhadap aktivitas siswa pada penelitian ini ada tujuh indikator yaitu: (1) Visual, (2) Oral, (3) Listening, (4) Writing, (5) Motor, (6) Mental, (7) Emotional.

\section{siklus II}

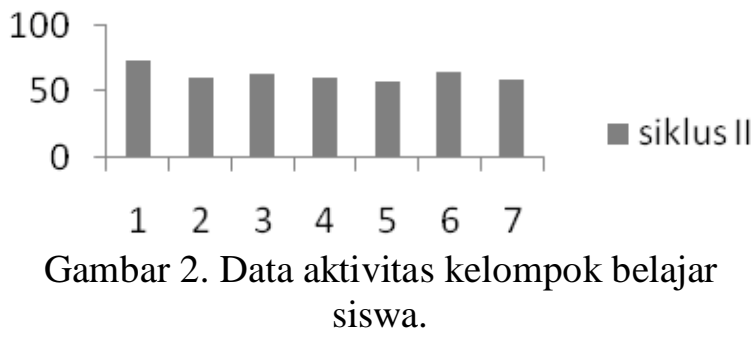

\section{Data Hasil Belajar.}

Tes hasil belajar pada akhir pembelajaran siklus pertama, diperoleh hasil penguasaan siswa terhadap materi belajar tergolong kurang yaitu dengan rata-rata 8,77 dari skor ideal 15 skor perolehan rata-rata hanya mencapai 10 atau persentase $58,92 \%$ dan siswa yang mencapai ketuntasan belajar hanya mencapai $19,35 \%$ atau sebanyak 6 orang dari 31 orang siswa. Perolehan nilai rata-rata tersebut dapat dijadikan sebagai tolak ukur bahwa masih lemahnya struktur kognitif siswa. Sehingga dibutuhkan pengusaan yang baik diterima siswa sehingga siswa dapat mengerjakan soal dan materi awal belum begitu dikuasai, akibatnya proses pembelajaran belum maksimal. hasil observasi terhadap aktivitas pembelajaran guru di kelas pada pertemuan pertama 81,65; pada pertemuan kedua meningkat menjadi 88,00 dan pada pertemuan ketiga meningkat lagi menjadi
95,20. Meskipun nilai peningkatannya kecil, tetapi aktivitas pembelajaran yang dilakukan guru di kelas tetap mengalami peningkatan.

Rata-rata untuk indikator peningkatan hasil belajar secara rata-rata ada peningkatan sebesar $19,36 \%$, yaitu dari $58,92 \%$ pada siklus pertama menjadi $75,70 \%$ pada siklus kedua dan akhir siklus kedua hasil pembelajaran sudah memenuhi harapan, yakni peningkatan hasil belajar siswa secara individu.

Untuk mengetahui kategori peningkatan hasil belajar dapat dilihat berdasarkan nilai gain ternormalisasi hasil belajar siswa yaitu 0,41 . Ini berarti telah terjadi peningkatan rata-rata skor tes hasil belajar sebesar 2 poin, persentase ketuntasan sebesar $61,24 \%$ dan peningkatan nilai tes hasil belajar berkategori sedang. Hal ini menunjukkan bahwa proses kinerja guru dan siswa pada siklus II tercapai secara optimal.

\section{Pembahasan}

Berdasarkan hasil yang diperoleh pada siklus kedua ini yaitu:

1. Aktivitas siswa dalam proses belajar mengajar sudah mengarah pada pembelajaran kooperatif tipe STAD melalui metode eksperimen. Hal ini dapat dilihat dari data hasil observasi terhadap indikator aktivitas belajar siswa meningkat dari 62,28 menjadi 71,95. Hal ini berarti aktivitas belajar tergolong pada kategori cukup. Kategori ini disebabkan oleh beberapa aspek aktivitas belajar siswa pada siklus II masih bertaraf lemah. Aspek-aspek tersebut antara lain aspek Oral, Motor, dan Emotional. (1) aspek Oral siswa pada siklus kedua tidak jauh berbeda dengan siklus pertama. Hal ini terjadi diperkirakan karna permasalahan bahasa yang masa siswa enggan berbicara karna kurang fasih berbahasa Indonesia. (2) Aspek Motor siswa pada siklus kedua juga tidak jauh berbeda dengan siklus pertama. Peningkatan pada aspek ini hanya terjadi pada beberapa orang siswa saja. Siswa yang mengalami peningkatan pada aspek ini setelah diselidiki ternyata siswasiswa yang memiliki kesadaran sendiri 
membentuk kelompok belajar sendiri di luar sekolah. (3) Aspek Emotional siswa pada siklus kedua ini dipengaruhi kondisi pada kedua aspek diatas seperti yang terlihat pada saat sesi diskusi di kelas dalam melakukan eksperimen terlihat hanya beberapa orang saja yang turut ikut andil misalnya dalam melakukan prosedur dari percobaan yang dilakukan atau menjawab pertanyaan dari kelompok sendiri maupun kelompok lain. Namun walaupun demikian pada siklus kedua ini indikator aktifitas belajar siswa telah mengalami peningkatan sesuai dengan hasil penelitian Okta (2010) melakukan penelitian tindakan kelas pada siswa SMA pada mata pelajaran ekosistem berkaitan pada peningkatan aktivitas belajar dalam penguasaan konsep melalui pembelajaran menggunakan metode eksperimen, ditemukan bahwa berdasarkan indikatorindikator keaktifan belajar siswa menunjukan perubahan dan peningkatan pada penguasan konsep siswa dan hasil belajar yang cukup signifikan pada setiap siklus.

2. Dengan melakukan eksperimen di kelas dalam pembelajaran dapat meningkatkan hasil belajar Fisika siswa yang ditandai dengan meningkatnya hasil belajar siswa sebesar 2 point atau $19,36 \%$ dari hasil rata-rata 9 pada skor ideal 15 atau 58,92\% (kategori cukup) pada siklus pertama menjadi 11 atau 93,54 (kategori baik) pada siklus kedua. Hal ini sesuai dengan hasil penelitian Kholifudin (2011) ditemukan bahwa pembelajaran Fisika dengan inkuiri terbimbing melalui metode eksperimen dan demonstrasi pada siswa SMA pada materi fluida statis diperoleh terdapat pengaruh metode eksperimen dan demonstrasi terhadap prestasi belajar Fisika siswa dan tidak ada pengaruh gaya belajar terhadap prestasi belajar Fisika pada pembelajaran

3. Gain ternormalisasi tes hasil belajar sebagai indikator peningkatan hasil belajar siklus II terhadap siklus I bernilai 0,41 . Nilai ini menjelaskan bahwa gain ternormalisasi untuk penguatan struktur kognitif berkategori sedang.

\section{SIMPULAN}

Penerapan model pembelajaran kooperatif dengan pemberian metode eksperimen dapat meningkatkan aktivitas dengan hasil observasi terhadap aktivitas pembelajaran guru di kelas pada siklus I dimana pada pertemuan pertama 65,60, pada pertemuan kedua meningkat menjadi 76,00 , dan pada pertemuan ketiga meningkat lagi menjadi 79,20. Meskipun nilai peningkatannya kecil, tetapi aktivitas pembelajaran yang dilakukan guru di kelas tetap mengalami peningkatan. Sedangkan hasil observasi terhadap aktivitas pembelajaran guru di kelas pada siklus II dimana pertemuan pertama 81,65 , pada pertemuan kedua meningkat menjadi 88,00, dan pada pertemuan ketiga meningkat lagi menjadi 95,20. Meskipun nilai peningkatannya kecil, tetapi aktivitas pembelajaran yang dilakukan guru di kelas tetap mengalami peningkatan aktivitas belajar siswa dengan metode eksperimen sebesar $17 \%$.

Dari hasil observasi menunjukkan bahwa peningkatan aktivitas belajar siswa meningkat pesat pada aspek visual, listening, dan motor yaitu dengan rerata masing-masing aspek visual dari 2,83 menjadi 3,75; aspek listening dari 2,89 menjadi 3,72; dan aspek motor dari 2,65 menjadi 3,65. Rata-rata penıngkatan hasil belajar siswa pada siklus I sebesar 58,92\% peningkatan hasil belajar secara rata-rata ada peningkatan sebesar $19,36 \%$, yaitu dari $58,92 \%$ pada siklus pertama menjadi $75,70 \%$ pada siklus kedua dan akhir siklus kedua hasil pembelajaran sudah memenuhi harapan, yakni peningkatan hasil belajar siswa secara individu. Peningkatan rata-rata skor tes hasil belajar sebesar 2 poin, persentase ketuntasan sebesar $61,24 \%$ dan peningkatan nilai tes hasil belajar berkategori sedang dengan nilai gain ternormalisasi 0,41. Melalui metode eksperimen, siswa membangun sendiri struktur kognitifnya, menemukan langkah-langkah dalam mencari penyelesaian dari masalah, baik secara individu maupun kelompok. 
Berdasarkan analisis data dapat diketahui bahwa ada peningkatan respon siswa kelas VIII SMP Negeri 2 Labuhan Deli melalui penerapan model pembelajaran kooperatif tipe STAD dalam propses pembelajaran Fisika. Data pengamatan respon siswa tentang pelaksanaan pembelajaran kooperatif tipe STAD dapat dilihat dari siswa yang memperoleh nilai pemahaman konsep Fisika berbeda dari yang nilainya di atas kriteria ketuntasan minimal, siswa yang memperoleh nilai pemahaman konsep Fisika berkisar nilai kriteria ketuntasan minimal, tetapi tergolong tuntas, dan siswa yang memperoleh nilai kurang dari nilai kriteria ketuntasan minimal.

\section{DAFTAR PUSTAKA}

Arends, R.I. 2008. Learning To Teach Buku Satu. Yogyakarta: Pustaka Pelajar.

Asma, N. 2006. Model Pembelajaran Kooperatif. Jakarta: Departemen Pendidikan Nasional.

Elizar. 2012. Meningkatkan Hasil Belajar Siswa Melalui Penerapan Metode Demonstrasi Di Kelas XI IPA-1 Pada Pelajaran Biologi. Jurnal Penelitian Tindakan Kelas. Vol. 1, No. 2 Desember 2012. hal. 94-101.

Sudjana, N. 2010. Penilaian Hasil Proses Belajar Mengajar. (Cet. XV). Bandung: PT. Ramaja Rosdakarya. 